\title{
Resistance of New Zealand Provenance Leptospermum scoparium, Kunzea robusta, Kunzea linearis, and Metrosideros excelsa to Austropuccinia psidii
}

\author{
Grant R. Smith, ${ }^{1, \dagger}$ Beccy J. Ganley, ${ }^{2}$ David Chagné, ${ }^{3}$ Jayanthi Nadarajan, ${ }^{3}$ Ranjith N. Pathirana, ${ }^{3}$ Julie Ryan, ${ }^{3}$ Elise A. Arnst, ${ }^{4}$ \\ Roanne Sutherland, ${ }^{5}$ Julia Soewarto, ${ }^{5}$ Gary Houliston, ${ }^{4}$ Alby T. Marsh, ${ }^{3}$ Emily Koot, ${ }^{3}$ Angus J. Carnegie, ${ }^{6}$ Tracey Menzies, ${ }^{7}$ \\ David J. Lee, ${ }^{8}$ Louise S. Shuey, ${ }^{7}$ and Geoff S. Pegg ${ }^{7}$ \\ ${ }^{1}$ The New Zealand Institute for Plant and Food Research Limited, Lincoln 7608, New Zealand \\ 2 The New Zealand Institute for Plant and Food Research Limited, Te Puke 3182, New Zealand \\ ${ }^{3}$ The New Zealand Institute for Plant and Food Research Limited, Palmerston North 4410, New Zealand \\ ${ }^{4}$ Manaaki Whenua Landcare Research, Lincoln 7608, New Zealand \\ ${ }^{5}$ Scion, Rotorua 3010, New Zealand \\ ${ }^{6}$ Forest Science, Department of Primary Industries-Forestry, Parramatta, NSW 2150 Australia \\ ${ }^{7}$ The Queensland Department of Agriculture and Fisheries, Brisbane, Queensland 4001, Australia \\ ${ }^{8}$ The University of the Sunshine Coast, Maroochydore, Queensland 4558, Australia
}

\begin{abstract}
Resistance to the pandemic strain of Austropuccinia psidii was identified in New Zealand provenance Leptospermum scoparium, Kunzea robusta, and $K$. linearis plants. Only 1 Metrosideros excelsa-resistant plant was found (of the 570 tested) and no resistant plants of either Lophomyrtus bullata or $L$. obcordata were found. Three types of resistance were identified in Leptospermum scoparium. The first two, a putative immune response and a hypersensitive response, are leaf resistance mechanisms found in other myrtaceous species while on the lateral and main stems a putative immune stem resistance was also observed. Both leaf and stem infection were found on $K$. robusta and $K$. linearis plants as well as branch tip dieback that developed on almost $50 \%$ of the plants. $L$. scoparium, $K$. robusta, and $K$. linearis are the first myrtaceous species where consistent infection of stems has been observed in artificial inoculation trials. This new finding and the first observation of significant branch tip dieback of plants of the two

Kunzea spp. resulted in the development of two new myrtle rust disease severity assessment scales. Significant seed family and provenance effects were found in L. scoparium, K. robusta, and $K$. linearis: some families produced significantly more plants with leaf, stem, and (in Kunzea spp.) branch tip dieback resistance, and provenances provided different percentages of resistant families and plants. The distribution of the disease symptoms on plants from the same seed family, and between plants from different seed families, suggested that the leaf, stem, and branch tip dieback resistances were the result of independent disease resistance mechanisms.

Keywords: cultivar resistance, disease development and spread, disease management, epidemiology, fungi, kānuka, mānuka, Myrtaceae, ornamentals, pandemic strain, pōhutukawa, ramarama, rawiri mānuka, rōhutu, trees, woody ornamentals
\end{abstract}

In April 2017, myrtle rust caused by the invasive fungal pathogen Austropuccinia psidii (Beenken 2017), synonym Puccinia psidii, a biotrophic fungus, was found on Metrosideros kermadecensis (Kermadec pōhutukawa) trees on Raoul Island, the most northern of the New Zealand Kermadec Islands (Anonymous 2019a; Ho et al. 2019). A month later, the pathogen was found on the North Island of New Zealand on M. excelsa plants in Kerikeri, Northland (Anonymous 2019b; Ho et al. 2019) and on myrtaceous plants in a nursey in Waitara, Taranaki (Anonymous 2019c). Nine genetic clusters of A. psidii have been recognized to date by Stewart et al. (2018). The New Zealand incursion was by the pandemic strain (du Plessis et al. 2019), which is represented by two genetic clusters, $\mathrm{C} 1$ and $\mathrm{C} 4$ (Stewart et al. 2018). This pathogen has an extensive host range of at least 480 species across 69 genera (Soewarto et al. 2019) and has been reported from a number of countries in the West Pacific and Southeast Asia region, including Hawaii (Uchida et al. 2006), Japan (Kawanishi et al. 2009), Australia (Carnegie et al. 2010), China-Hainan (Zhuang and Wei 2011), New Caledonia (Giblin 2013), Indonesia (McTaggart et al. 2016), and

${ }^{\dagger}$ Corresponding author: Grant. R. Smith; grant.smith@plantandfood.co.nz

Funding: We acknowledge support provided by the Ministry for Primary Industries, New Zealand (RFP18608) and Ministry of Business, Innovation and Employment, New Zealand (Catalyst C11X1607).

The author(s) declare no conflict of interest.

Accepted for publication 12 January 2020.

C 2020 The American Phytopathological Society
Singapore (du Plessis et al. 2019). This macrocyclic pathogen is known to produce three types of spores; whereas the bright yelloworange urediniospores are the dominant infective propagule, brown teliospores can be found on infected plants (Pegg et al. 2014) and basidiospores have been demonstrated to be infective, and the resulting sori recombinant (McTaggart et al. 2018).

The genus Metrosideros contains 12 native New Zealand species (de Lange and Rolfe 2010), including M. excelsa (pōhutukawa), an iconic, culturally significant, and widely planted amenity tree often referred to as the New Zealand Christmas tree, which produces an extensive display of (usually) red flowers in December to January. $M$. excelsa is often found on exposed coastal headlands and cliffs in northern New Zealand, inland near lakes or rivers, or as coastal forest stands (Bylsma et al. 2014). Pōhutukawa, as part of New Zealand's native biota, is taonga (treasure), and some trees have exceptional cultural significance, such as Te Waha O Rerekohu in Te Araroa, East Cape, which is estimated to be 600 years old (Anonymous 2019d).

The other five myrtaceous genera that contain species native to New Zealand are Leptospermum, Lophomyrtus, Neomyrtus, Syzygium, and Kunzea (de Lange and Rolfe 2010). Kānuka, the common name for a number of the Kunzea spp., is mostly used to describe Kunzea robusta, 1 of 10 species recognized following a revision of the $K$. ericoides complex by de Lange (2014). Including exotic species, New Zealand currently has over 100 Myrtaceae species from 43 genera (Buys et al. 2016), a relatively small percentage of the worldwide total of 5,950 species in the 132 genera of this family (Christenhusz and Byng 2016).

Leptospermum scoparium is native to both New Zealand and Australia; it is one of over 80 Leptospermum spp. found in Australia, New Zealand, and Southeast Asia (Anonymous 2019e). In New 
Zealand L. scoparium, commonly known as mānuka, kahikatoa, or New Zealand tea tree, is an aggregation of species and subspecies that requires critical reevaluation (de Lange 2014). Thus, currently (after the Kunzea revision), the 12 Metrosideros spp., 1 L. scoparium sp., 10 Kunzea spp., 2 Lophomyrtus spp., 1 Neomyrtus sp., and 1 Syzygium sp. constitute a total of 27 species in six genera of native New Zealand Myrtaceae species (de Lange 2014; de Lange and Rolfe 2010).

Mānuka is naturally present on shrubland throughout New Zealand (Wiser and Hurst 2008) because it is tolerant of environment extremes (e.g., drought and waterlogging) (Anonymous 2019f). Kānuka is a tall shrub or tree found throughout New Zealand, sometimes with mānuka (Allen et al. 1992). It is also tolerant of a range of environmental conditions; for example, it can be found growing near active geothermal systems (Anonymous 2019f). In 2012-13, 1.173 Mha of New Zealand's land area (approximately $4.4 \%$ of total) was classified as "mānuka and/or kānuka indigenous vegetation class", a reduction of 1.6\% from that recorded in 1996-97 (Dymond et al. 2017). Mānuka and kānuka produce nectar that has significant antibacterial and bioactive properties (Lu et al. 2013; Smallfield et al. 2018) and there is significant investment and activity to develop and grow New Zealand provenance mānuka and kānuka honey industries (Anonymous 2019g). A recent review of the potential impact of $A$. psidii on the New Zealand Forestry Industries noted that "potentially the greatest impact could be in native forest or scrubland" and that here could "...be serious consequences for the manuka honey industry" (Hood 2016).

A. psidii has been present is Australia since April 2010 (Carnegie et al. 2010), and has been spread by both natural processes (e.g., wind) and human social-economic activity (e.g., transport of asymptomatic infected plants) along most of the eastern seaboard (east of the Great Dividing Range), as far south as Tasmania and as far west as Melville Island (Timor Sea, north of Darwin). One component of the Australian scientific response to this incursion was the assessment of $A$. psidii resistance in artificially inoculated plants grown from seed (Morin et al. 2012; Pegg et al. 2014; Sandhu and Park 2013), scoring the response using a variation of the Junghans leaf infection scale originally developed in Brazil (Junghans et al. 2003a). Resistance to A. psidii infection was found in a range of native Australian species. Furthermore, the geographic origin of the seed source had a significant effect on the number of individual plants that were resistant in that species. In general, seed collected from plants from drier regions contained more resistant individuals (Freeman et al. 2019; Lee et al. 2015; Pegg et al. 2014). Both L. scoparium and $M$. excelsa were assessed in one of the Australian resistance assessment trials, with the origin of the seed listed as Australian (Sandhu and Park 2013). M. excelsa was also reported as a host species for the pathogen in Hawaii (Anonymous 2015). The provenance origins of both the seed assessed in Australia and the plants surveyed in Hawaii were unclear, reducing the value of these results when considering the potential impact of $A$. psidii on New Zealand's endemic and native Myrtaceae populations.

Here, we report the first assessments of germplasm from six myrtaceous species-M. excelsa (pōhutukawa), L. scoparium (mānuka), K. robusta (kānuka), K. linearis (rawiri mānuka), L. bullata (ramarama), and L. obcordata (rōhutu)—of New Zealand provenance for resistance to the pandemic strain of $A$. psidii, and discuss the findings in the context of options to maintain these species within ecosystems.

\section{Materials and Methods}

Agreement to collect and test germplasm. Māori authority over natural resources is defined in Te Tiriti o Waitangi (Treaty of Waitangi) (Anonymous 2019h), a treaty signed by Māori rangatira (chieftains) and the British Crown in 1840. Additionally, in 1993, Māori claims to plant species and cultural knowledge and intellectual property derived from them were lodged with the Waitangi Tribunal (Anonymous 2019i), a standing commission of inquiry that “... makes recommendations on claims brought by Māori relating to legislation, policies, actions or omissions of the Crown that are alleged to breach the promises made in the Treaty of Waitangi".
Accordingly, permissions were obtained before any seed was collected for use in this study. Prior to the collection of the $L$. scoparium seed, discussions leading to agreement were undertaken with representatives of Ngāti Porou Miere Limited. Similarly, discussions and subsequent agreements were established with mana whenua (Māori who have historical and territorial rights over the land) for the collection of $K$. robusta, $K$. linearis, L. bullata, L. obcordata, and M. excelsa seed, as well as for the collection of additional $L$. scoparium seed. For seed collected from private property, landowner permission was also obtained.

Seed collection and preparation. To determine the susceptibility of New Zealand Myrtaceae species to A. psidii, seed from L. scoparium, $K$. robusta, $K$. linearis, $M$. excelsa, L. bullata, and $L$. obcordata were collected from plants growing in different regions (provenances) of the North Island of New Zealand. Seed was collected from individual plants and uniquely numbered to maintain seed family identification. Seed were prepared and treated at The New Zealand Institute for Plant and Food Research Limited facilities at Palmerston North as prescribed under Australian Government Permit 0002144655, a permit obtained to import conditionally nonprohibited goods issued under the Biosecurity Act 2015 Section 179 (1), into Australia.

Seedling germination and preparation. Seed were germinated at a secure Queensland Government glasshouse and sown in 40-celled hico trays with plastic inserts $(70 \mathrm{ml})$ in the glasshouse using a potting medium consisting of $50 \%$ pine bark fines ( 0 to $10 \mathrm{~mm}$ ), $25 \%$ pine bark peat, $25 \%$ coarse perlite, a mix of 12- to 14-month slowrelease Osmocote (N-P-K 17.9:0.8:7.3) fertilizer at a rate of $4 \mathrm{~kg} / \mathrm{m}^{3}$, gypsum at $1 \mathrm{~kg} / \mathrm{m}^{3}$, Micromax at $1 \mathrm{~kg} / \mathrm{m}^{3}$, and a granular wetting agent, Hydroflo2, at $1 \mathrm{~kg} / \mathrm{m}^{3}$. Seedling establishment was initiated under glasshouse conditions and the seedlings were thinned over time to a single plant per cell. These seedlings were then transitioned to shade houses and irrigated twice a day for $10 \mathrm{~min}$ each time using an overhead spray. To ensure that plants were actively producing new growth flush at the time of inoculation, plants were fertilized 2 weeks prior to inoculation. When plants were sufficiently mature (approximately 3 months of age) for artificial inoculation, assessment trials were established using a randomized incomplete block design with at least a single plant from each seed family in each block. Because of the small numbers of provenances and seedlings tested for M. excelsa, L. bul$l a t a$, and $L$. obcordata, trials were designed using a randomized complete block design rather than an incomplete block design. Seedlings from three provenances of Melaleuca quinquenervia (Australian paper bark) were included as positive controls for $A$. psidii infection. These $M$. quinquenervia seed families had previously been tested (Pegg et al. 2018) and have a range of susceptibilities within the provenances. Plants were then moved to the Ecosciences Precinct in Brisbane, where controlled-environment rooms are available for plant inoculation.

Inoculum. A. psidii urediniospores used in inoculation trials were collected from infected Syzygium jambos trees from locations in Brisbane. Collected spores were sieved to remove extraneous matter before being placed in a desiccator for 5 to 7 days. Spores were then transferred into vials and placed into a $-80^{\circ} \mathrm{C}$ freezer until required. Just prior to inoculation, urediniospores were removed from $-80^{\circ} \mathrm{C}$ storage and added to sterile distilled water (SDW) along with Tween 20 (two drops per $100 \mathrm{ml}$ of SDW) as a surfactant. Spore counts were undertaken prior to inoculation using a hemocytometer, with the suspension adjusted to a concentration of $1 \times 10^{5}$ spores $/ \mathrm{ml}$.

Inoculation. Seedlings were placed onto a plastic-lined bench and then inoculated using a fine mist spray ( $29 \mathrm{kPa}$ pressure), using a compressor-driven spray gun (Iwata Studio series 1/6 hp; Gravity spray gun RG3). Inoculum was applied to the upper and lower leaf surfaces and stems of the seedlings, ensuring that all leaves were coated with a fine mist but spore suspension run-off was avoided. Once inoculated, seedlings were covered with plastic sheeting to create a sealed environment for the maintenance of humidity and leaf wetness. Hot tap water $\left(60^{\circ} \mathrm{C}\right)$ was applied to the lower plastic sheet immediately before plants were placed into a controlled-environment chamber to ensure that high humidity and leaf wetness were achieved rapidly. The benches of seedlings were then maintained in darkness 
for $24 \mathrm{~h}$ at $18^{\circ} \mathrm{C}$ and $80 \%$ relative humidity. After $24 \mathrm{~h}$, the plastic coverings were removed and seedlings were transferred into a shade house and watered for $10 \mathrm{~min}$, twice daily.

Assessment. Following inoculation, symptom development and progression were monitored and disease assessment was conducted when disease levels were optimal (approximately 20 to 25 days postinoculation). Assessments were conducted using the modified Junghans scale (Pegg et al. 2014), defined as L1 to L5 in this study (Table 1) for leaf symptom expression (Fig. 1). While monitoring disease symptom development prior to assessment of the first batch of New Zealand provenance mānuka, varying degrees of stem infection on plants were noted (Fig. 2). The variability in the stem infection symptoms observed could not be captured accurately using the modified Junghans scale, so an additional stem assessment scale (S1 to S8) was developed (Table 2). Furthermore, during monitoring of disease symptoms on the first batch of New Zealand provenance Kunzea spp., significant branch tip dieback (BTD) was noted on plants from some seed families (Fig. 3) and a scale (BTD1 to BTD5) to measure this symptom was developed (Table 3).

Analyses. Individual plant-, seed family-, and provenance-level results were assembled from the experimental results using Microsoft Excel functions, including INDEX, MATCH, and COUNTIF, within array formulas for analysis. Seed families with fewer than eight assessed plants were excluded from further analysis. Although Pegg et al. (2014) considered plants assessed as L1 to L3 on the modified Junghans scale to be indicating resistance, for these analyses, L3 was considered to be moderately susceptible for the subsequent plant, family, and provenance analyses. $M$. excelsa and $K$. robusta plants with L1, L2, or S1 ratings were considered to have leaf or stem resistance, respectively; $K$. robusta or $K$. linearis plants with a BTD1 rating were considered to be resistant to BTD. Plants with a rating in the ranges of $\mathrm{L} 3$ to $\mathrm{L} 5, \mathrm{~S} 2$ to $\mathrm{S} 8$, and BTD2 to BTD5 were considered to be susceptible to leaf, stem, or branch tip infection, respectively. The Metrosideros excelsa (pōhutukawa), Lophomyrtus bullata (ramarama), and L. obcordata (rōhutu) disease assessment data sets were too limited for analysis and, thus, only the disease score totals are reported.

\section{Results}

Symptoms of $A$. psidii infection were identified on all species assessed, appearing as early as 5 days postinfection. The rate of symptom development over the 20 to 25 days prior to assessment were similar to that observed in the known susceptible species $M$. quinquenervia (used as a control), initially appearing as red- or purple-colored spots on young foliage and juvenile stems, with uredinia and urediniospores appearing soon after on foliage, shoots, and juvenile stems. Teliospores were frequently observed on the foliage of the two Kunzea spp. and $L$. scoparium but were less common on stem lesions. Teliospores were also present on M. excelsa and two Lophomyrtus spp. Symptoms of foliage and stem blight were also observed on the most susceptible M. excelsa and Lophomyrtus spp. seedlings.

Infection severities and resistance levels within $M$. quinquenervia provenances used as controls in this study were comparable with those published by Pegg et al. (2018), demonstrating the accuracy and repeatability of the experiments.

Leptospermum scoparium. Plants grown from seed collected from 132 L. scoparium (mānuka) seed families in four provenances-North,

Table 1. Leaf disease visual assessment scale, modified from the Junghans scale, for scoring symptom development on plants infected by Austropuccinia psidii used in this study

\begin{tabular}{ll}
\hline Scale & \multicolumn{1}{c}{ Leaf visual symptoms } \\
\hline L1 & No symptoms or presence of flecking (yellow or clear) evident \\
L2 & Presence of a hypersensitive reaction, with fleck or necrosis \\
L3 & Small pustules, $<0.8 \mathrm{~mm}$ in diameter, with one or two uredinia \\
L4 & $\begin{array}{c}\text { Medium-sized pustules, } 0.8 \text { to } 1.6 \mathrm{~mm} \text { in diameter, with about } 12 \\
\text { uredinia }\end{array}$ \\
L5 & $\begin{array}{c}\text { Large pustules, }>1.6 \mathrm{~mm} \text { in diameter, with } 20 \text { or more uredinia on } \\
\end{array}$ \\
\hline
\end{tabular}

East, East Cape, and West-Central of the North Island of New Zealand-were assayed for resistance to A. psidii. Variable rates of stem infection were noted (Fig. 2) during the assay, at times when no foliage infection was evident, and a stem severity rating scale (described above; Table 2) was developed to capture this variability in infection reaction because it could not be captured using the modified Junghans scale. In this stem rating scale, $\mathrm{S} 1$ is resistant along with the leaf resistance categories L1 and L2, previously described as 1 and 2 in the modified Junghans rating scale (Pegg et al. 2014). Leaf resistance (either L1 or L2) was observed in plants grown from $75 \%$ of seed families (Table 4), with most of the leaf resistance expressed as the L1 phenotype (47.7\%; Table 4). Almost a third of the resistance families (30 of 99; Table 4) produced plants that expressed either the L1 or the L2 resistant phenotype, while just 6 of the resistant families ( $4.5 \%$ of the total) produced plants that showed only the L2 phenotype.

When assessing severity of stem infection, there were extensive symptoms on the stems and limited (or no) leaf symptoms on some plants. However, $83.3 \%$ of the families produced plants that had an S1 stem resistance phenotype and $62.1 \%$ of the families produced plants that had either L1 or L2 leaf resistance and S1 stem resistance (Table 4), with the majority of the families producing plants with L1, S1 resistance either uniquely $(40.9 \%)$ or as plants with either the L1, $\mathrm{S} 1$ or the L2, S1 phenotypes (18.9\%). Only $2.3 \%$ of the seed families produced plants that only had a L2, S1 resistance phenotype. Plants with no resistance to either leaf or stem infection were produced by $12.1 \%$ of the seed families, while another $17.4 \%$ of the families produced plants that were resistant to either leaf or stem infection but not to both.

Although both leaf and stem resistance were observed in plants produced by most of the seed families, only a quarter of the individual plants assayed showed either resistance $(25.7 \% \mathrm{~L} 1$ or L2 and $27.1 \%$ S1; Table 5). Only $15.1 \%$ of the individual plants assayed showed both leaf (either L1 or L2) and stem (S1) resistance, with the majority of these plants (12.6\% of the total assayed) expressing the L1, S1 phenotype (Table 5).

On average, there were just over 13 plants per family assayed (the range was 8 to 23 plants per family) and an average of just over 3 resistant plants per family expressing the double (S1 and either L1 or L2) resistance phenotype.

A provenance effect was evident in the geographic distribution of leaf and stem resistance to A. psidii infection in mānuka (Fig. 4). For example, the East region contributed over $54 \%$ of the L1 resistant plants while providing only $33 \%$ of the plants, compared with the North region which, while providing $38 \%$ of the plants overall, contributed only $20 \%$ of the L1 resistant plants.

A small number of plants had flower buds/flowers present at the time of inoculation. A. psidii pustules were present on various parts of the flower buds and flowers including the peduncle, receptacle, sepals (calyx) and petals (Fig. 5), causing dieback of flowers and in some cases resulting in flower bud death.

K. robusta and $K$. linearis. Seed from two species of Kunzea-K. robusta (23 families) and $K$. linearis (5 families)—were collected

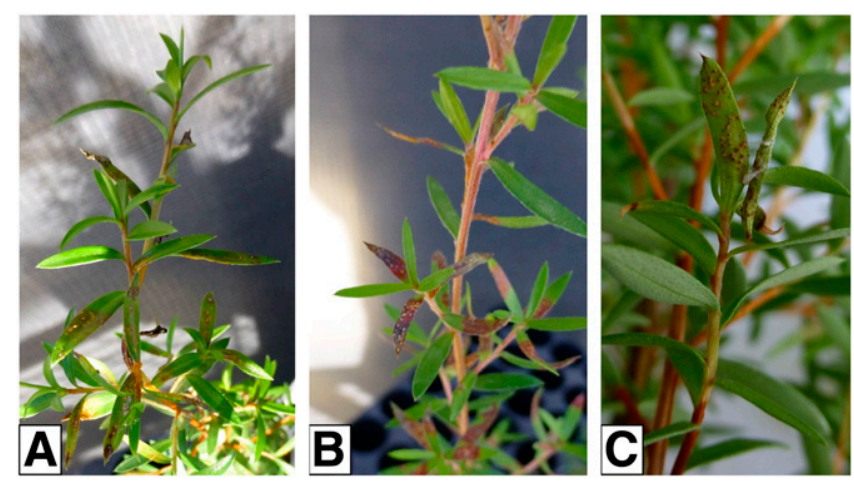

Fig. 1. New Zealand provenance Leptospermum scoparium (mānuka) plants infected by Austropuccinia psidii showing myrtle rust leaf symptoms of A, uredia and urediniospores; B, lesions, uredia, and urediniospores; and C, telia and teliospores. 
from four geographic provenances in the North Island: Northland, Auckland, Coromandel, and Bay of Plenty. Similarly to L. scoparium, most of the Kunzea spp. seed families (96.4\%; Table 6) produced plants that expressed either the L1 or L2 leaf resistance phenotype. In contrast to mānuka, the dominant leaf resistance phenotype was the hypersensitive response L2 that was observed in plants from 25 of the Kunzea families. In 12 families, L2 was the only leaf resistance phenotype observed. Only one $K$. linearis seed family did not produce plants with leaf resistance (L1 or L2).

Many of the families (89.3\%; Table 6) also produced plants that expressed the $\mathrm{S} 1$ stem resistance phenotype that had been observed in mānuka. Three seed families did not produce S1 stem infectionresistant plants: two $K$. linearis families (including the one family that produced no plants with leaf resistance) and one $K$. robusta family. Almost half $(n=13)$ of the families produced plants with only the L2, S1 phenotype; 5 families produced plants with only a L1, S1 resistance phenotype while 7 families produced plants with (L1 or L2) and $\mathrm{S} 1$ resistance. Interestingly, because the S1 phenotype criterion was applied to the analysis, the number of only L1 resistance plants increased from two to five (only L1 and S1) (Table 6). This was a consequence of the $\mathrm{S} 1$ resistance not being found with $\mathrm{L} 2$ resistance in three families that produced both L1 and L2 plants, moving three families from the either L1 or L2 and S1 plants phenotype group to the only $\mathrm{L} 1$ and $\mathrm{S} 1$ phenotype group.

Another disease symptom, BTD, was observed on almost half the Kunzea plants during the trial (Fig. 3), yet the resistant phenotype, BTD1, was found in plants from all 28 families. Overall, although 25 of the 28 families produced plants that expressed leaf, stem, and BTD resistance to $A$. psidii infection, the number of plants that expressed all three of these resistances was only $13.3 \%$ of the total assayed (Table 7).

On average, almost 13 plants per family were assayed (a range of 9 to 15) and an average of 2 resistant plants per family had the triple (L1 or L2, S1, BTD1) resistance phenotype.

The relatively small number of Kunzea spp. families and plants assessed showed some limited provenance effects (Fig. 6). None of the 61 plants (17\% of total plants collected) from the Auckland region expressed the L1 phenotype; however, 37\% expressed the L2 phenotype. A third (33\%) of the plants grown from seed collected in the Bay of Plenty (14\% of total plants collected) expressed the L1 phenotype (Fig. 6). All 70 plants grown from seed collected in Northland were $K$. linearis. Only three plants expressed the S1 phenotype, and they were more susceptible to BTD than plants from any of the other regions (BTD2 to $-5,67 \%$ of plants assayed).

M. excelsa. The seed collected from 31 pōhutukawa seed families from four provenances produced 570 plants (Table 8 ). Only one plant with L1 leaf resistance was observed in the 570 plants tested (Table 8). No L2 hypersensitive response was noted, with over half (56.5\%) of the plants rated as L5 (highly susceptible).

L. bullata and $L$. obcordata. The 56 plants from three $L$. bullata families only showed leaf symptoms ranging from L3 to L5, with an average rating per plant of 4.9 (highly susceptible) (Table 8). The five L. obcordata plants from one family also only showed leaf symptoms ranging from L3 to L5, with an average rating of 4.4 (highly susceptible) (Table 8).

\section{Discussion}

This is the first detailed study of $A$. psidii infection on native New Zealand Myrtaceae species and results showed that there is resistance to A. psidii infection in L. scoparium (mānuka), K. robusta (kānuka), and $K$. linearis (rawiri mānuka). There is also significant susceptibility to this pathogen in these species. Very limited resistance was identified in M. excelsa (pōhutukawa) and larger studies are required to determine whether the extent of susceptibility observed in this study is reflected in the broader population. No resistance was found in either L. bullata (ramarama) or L. obcordata (rōhutu) in the limited number of plants assessed. The Lophomyrtus spp. findings reflect field observations of infection in New Zealand (Anonymous 2019j).

Myrtle rust disease severity rating systems have evolved, especially under field conditions and as scientists have developed a better understanding of different host responses to infection and subsequent impacts over time (Berthon et al. 2018; Pegg et al. 2018). In this study, the Junghans et al. (2003a) assessment system could not capture the variability in severity of stem infection and tip dieback observed on L. scoparium and Kunzea spp. seedlings. Thus, additional rating categories were developed and implemented for
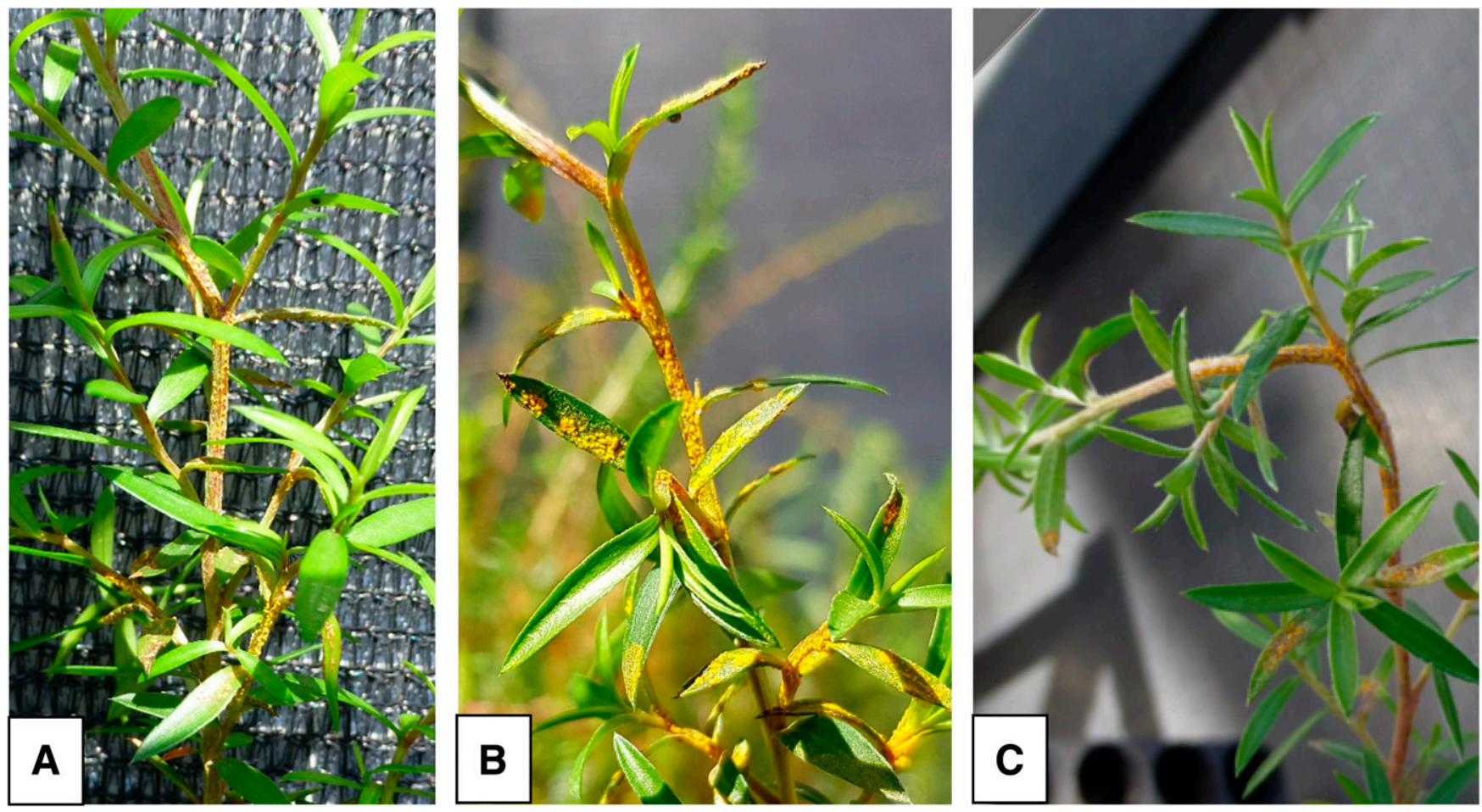

Fig. 2. New Zealand provenance Leptospermum scoparium (mānuka) plants infected by Austropuccinia psidii showing myrtle rust stem symptoms of $\mathbf{A}$, extensive uredia and urediniospores on the stem and limited uredia and urediniospores on leaves; B, extensive uredia and urediniospores on both stems and leaves; and C, uredia and urediniospores on both stems and leaves, and crooking of the main lateral stem. 
L. scoparium and Kunzea spp. from those previously used during studies on infection of a range of eucalypts in Brazil and Australia and melaleuca in Australia (Junghans et al. 2003b; Lee et al. 2015; Pegg et al. 2014, 2018). Because of the variability in severity of stem infection and tip dieback observed between seedlings, and at times the presence of stem infection in the absence of any foliage symptoms, it was important to gather these additional data. These symptoms observed on L. scoparium and Kunzea spp. seedlings were unlike the symptoms noted on the $M$. quinquenervia plants that were used as controls in this study, where stem infection is closely related to the severity of foliage infection. The findings of substantial stem infection in L. scoparium, $K$. robusta, and $K$. linearis, as well as BTD in the two Kunzea spp., are significant and are not artifacts of the assay. The most susceptible M. excelsa, L. bullata, and L. obcordata seedlings also suffered severe leaf blighting, which limited the size of lesions and number of pustules. Because of the effect on the seedlings, this blight symptom was considered to rank within the highest severity category (L5). These findings suggest a more complex set of host-pathogen interactions than has previously been observed in other myrtaceous species (Junghans et al. 2003b; Lee et al. 2015; Morin et al. 2012; Pegg et al. 2014, 2018; Sandhu and Park 2013). However, it is still uncertain how these disease symptoms and severity levels in an experimental environment translate into disease

Table 2. Stem disease visual assessment scale for scoring symptom development on plants infected by Austropuccinia psidii used in this study

\begin{tabular}{ll}
\hline Scale & \multicolumn{1}{c}{ Stem visual symptoms } \\
\hline S1 & No evidence of infection on main or lateral stems \\
S2 & Pustule present on stems but no lesion \\
S3 & 1 to 2 stem lesions; average length $<5 \mathrm{~mm}$ \\
S4 & 1 to 2 stem lesions; average length $\geq 5 \mathrm{~mm}$ \\
S5 & $>2$ but $<5$ stem lesions; average length $<5 \mathrm{~mm}$ \\
S6 & $>2$ but $<5$ stem lesions; average length $\geq 5 \mathrm{~mm}$ \\
S7 & $\geq 5$ stem lesions; average length $<5 \mathrm{~mm}$ \\
S8 & $\geq 5$ stem lesions; average length $\geq 5 \mathrm{~mm}$ \\
\hline
\end{tabular}

impact under natural conditions, including effects on growth, survival, and fecundity, and these require further investigation.

The finding of an extremely low level of resistance to A. psidii in New Zealand provenance $M$. excelsa is especially troubling, because pōhutukawa is a culturally significant species and has an important ecological role in stabilizing coastal and inland water shores from erosion, limiting the influx of sediment into coastal and inland waterways. The susceptibility of M. excelsa, L. bullata, and L. obcordata is consistent with the field surveillance findings (last published in September 2018) where "Ramarama: Lophomyrtus spp." and "Pōhutukawa, Northern rata, Southern rata: Metrosideros spp." were the most common confirmed infected species of Myrtaceae (Anonymous 2019j). In contrast, field detections of infected mānuka have been limited ( 3 from 19,808 field surveillance observations) (Anonymous 2019j). This is surprising considering the number of susceptible seedlings and severity of infection observed in this study. In Australia, a range of eucalypts - for example, Eucalyptus cloeziana (Lee et al. 2015), E. grandis (Roux et al. 2015), and Corymbia citriodora (Pegg et al. 2014) - have been tested and shown to have susceptibility within populations; however, field detections were limited (Carnegie 2015). Furthermore, A. psidii infection on native Australian Leptospermum spp. (L. polygalifolium, $L$. liversidgei, and L. trinervium) is more apparent on regrowth following disturbance events such as wildfire or storm damage (G. S. Pegg, P. Entwhistle, F. R. Gilbin, and A. J. Carnegie, unpublished), suggesting that plant growth stage may influence disease development in the field. Alternatively, the different types of leaf and stem symptoms on the New Zealand $L$. scoparium in these trials may mean that symptoms on field plants were missed, or that the plants observed may not have been exposed to $A$. psidii inoculum. There is still a limited understanding of field disease epidemiology in New Zealand for the native Myrtaceae species and the ecosystems in which they exist, and there are likely to be many factors influencing disease development and severity resulting from $A$. psidii infection in the natural estate.

The two different leaf resistance phenotypes observed in L. scoparium putatively represent an immune response (L1) and a hypersensitive response (L2) sensu Butler et al. (2016). Overall, leaf
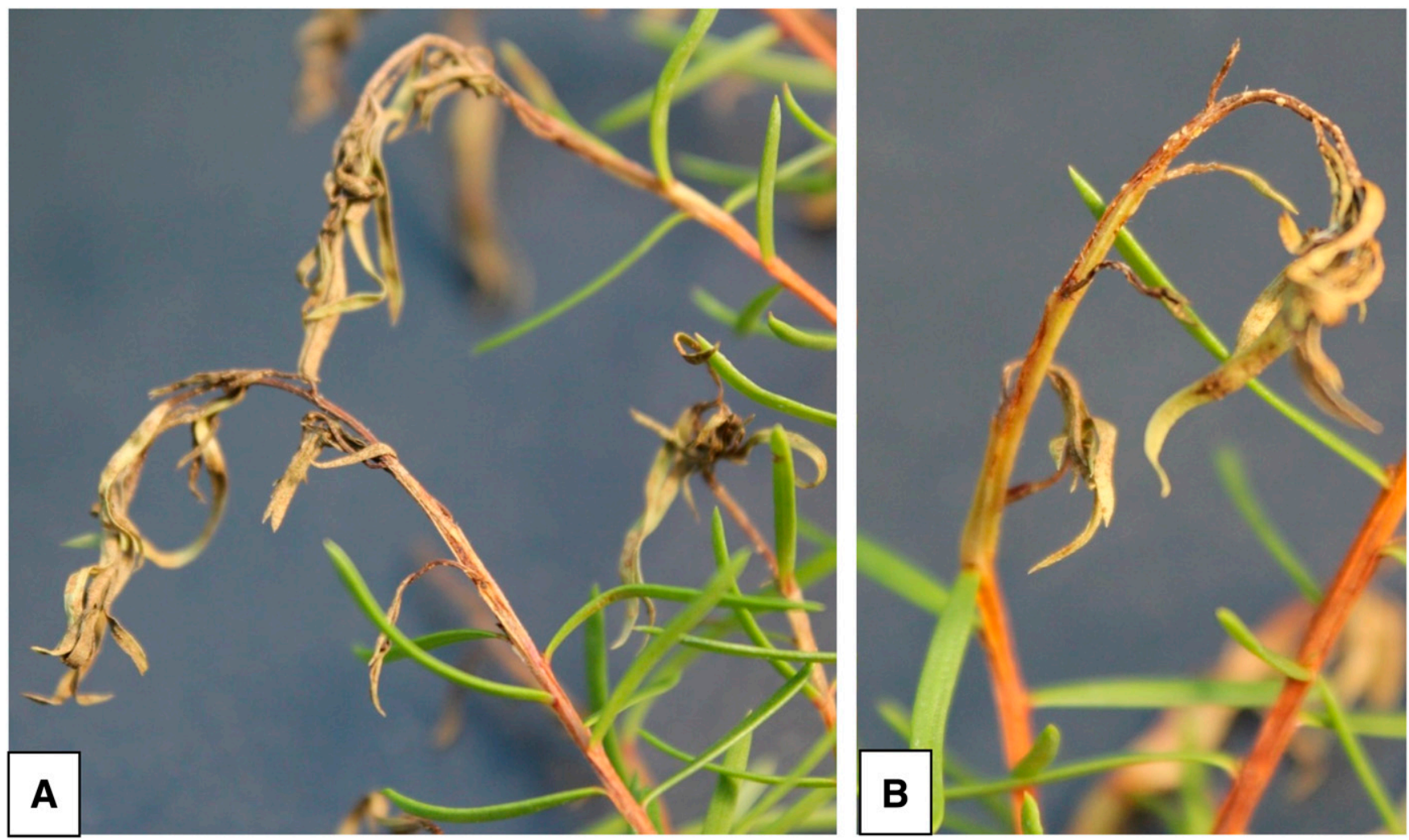

Fig. 3. A and B, New Zealand provenance Kunzea sp. plants infected by Austropuccinia psidii showing substantial branch tip dieback with no disease symptoms on the leaves. 
resistance was found in $75 \%$ of the $L$ scoparium families but the distribution of the two resistance mechanisms in these families suggests a limited genetic linkage between the putative L1 immune and L2 hypersensitive resistance mechanisms, because plants from 63 of the families tested only expressed L1 leaf resistance and 6 families only the 2 phenotype, while 30 of the families expressed both (Table 4).

The stem resistance phenotype $\mathrm{S} 1$, which appears to be an immune resistance, also did not appear to have a close genetic linkage with either of the leaf resistance phenotypes (L1 or L2). Although S1 was observed in $83.3 \%$ of the families tested, only $62.1 \%$ of the families produced plants with both stem and leaf resistance (Table 4). Individual plants with L1 leaf resistance had stem resistance scores ranging from $\mathrm{S} 1$ to $\mathrm{S} 8$, suggesting that the basis of these two resistance mechanisms are different. Alternatively, these distinct phenotypes could be the result of tissue-specific differential expression. Plants with the L2 leaf resistance phenotype showed stem resistances ranging from S1 to S6, again suggesting no significant genetic linkage between the putative $\mathrm{L} 2$ and $\mathrm{S} 1$ resistance mechanisms. The reason for the relative paucity of $\mathrm{L} 2$ resistance in $L$. scoparium compared with the two Kunzea spp. is unknown. A limited number of L. scoparium flowered during this study, and those flowers were able to be infected. Further investigation is required to examine the field impacts of $A$. psidii infection on flower production, survival, and pollination processes, including in those lineages considered resistant based on foliage and stem symptoms.

At the family level, there are a number of leaf and stem resistance combinations that are likely to result in field susceptibility for plants from those families. These include families (12.1\%) that produced plants with no leaf or stem resistance, families that produced no plants with leaf resistance (25\%), and families (16.7\%) that produced no plants with stem resistance. Although $62.1 \%$ of the families produced plants with both leaf and stem resistance, not all plants in these families had both resistance mechanisms; these families produced, on average, 3.2 plants with both leaf and stem resistance (range was 1 to 12 resistant plants per family). The underlying genetic mechanisms for these resistance traits appear to be widespread in the plant populations but only occur in a limited number of plants, perhaps because of limited selection pressure to date to increase their presence (or expression) in individual plants. Whether these resistance mechanisms are effective against other pathogens of $L$. scoparium is unknown. The only other $L$. scoparium disease recorded in New Zealand is mānuka blight, a sooty mold caused by Capnodium walteri growing on honeydew resulting from feeding by the scale insect Eriococcus manukae (Mulcock 1954).

The genetic diversity of $L$. scoparium in New Zealand is geographical, with variation between the northern North Island, the central and southern North Island, and the South Island (Buys et al. 2019). Further, the current taxonomic status of L. scoparium in New Zealand is an aggregate that requires critical revaluation (de Lange 2014). Forming an understanding of the Leptospermum population structure, in particular understanding the distribution of these resistance mechanisms and described variation into any new proposed species, may assist both in understanding the complexity of the results found in this study and in formulating specific germplasm conservation strategies.

The two Kunzea spp. were analyzed together, because the number of seed families and plants was limited. Almost all (96.4\%) the

Table 3. Branch tip dieback (BTD) visual assessment scale for scoring symptom development on Kunzea spp. plants infected by Austropuccinia psidii used in this study

\begin{tabular}{ll}
\hline Scale & \multicolumn{1}{c}{ Visual symptoms } \\
\hline BTD1 & No dieback \\
BTD2 & 1 to $25 \%$ of tips on a plant showing dieback \\
BTD3 & 26 to $50 \%$ of tips on a plant showing dieback \\
BTD4 & 50 to $75 \%$ of tips on a plant showing dieback \\
BTD5 & 76 to $100 \%$ of tips on a plant showing dieback \\
\hline
\end{tabular}

families produced plants with leaf resistance (L1 or L2) and most $(89.3 \%)$ of those families also produced plants with $\mathrm{S} 1$ resistance. BTD has not been a disease symptom previously used to assess susceptibility to A. psidii but, when it was added to the resistance criteria in this study, $89.3 \%$ of the families were found to produce plants with leaf, stem, and BTD resistance. Interestingly, one $K$. linearis family produced five plants with BTD1 branch resistance but no plants with (L1 or L2) leaf or S1 stem resistance, suggesting that BTD resistance is mediated via a different mechanism from the other three resistances. Under natural conditions, tip and branch dieback may prevent or reduce flower bud production and may result in a significantly altered architecture of surviving plants. In situations where the plant is not killed, this dieback could result in trees with a more shrub-like form rather than the typical midheight $(12 \mathrm{~m} \mathrm{~K}$. linearis) to tall ( $30 \mathrm{~m}$ K. robusta) trees. Significant changes in plant growth and habit have been recorded for a range of species in Australia following repeated $A$. psidii infection and subsequent dieback or loss of apical shoots and side branches (Carnegie et al. 2016; Pegg et al. 2017).

Table 4. Distribution of leaf (L1, L2) and stem (S1) resistance to infection by Austropuccinia psidii in plants from seed families of New Zealand provenance Leptospermum scoparium (mānuka)

\begin{tabular}{lcc}
\hline Resistance phenotype & $\begin{array}{c}\text { Total number of } \\
\text { families }\end{array}$ & $\begin{array}{c}\text { Percentage of total } \\
\text { families (\%) }\end{array}$ \\
\hline Total & 132 & 100 \\
$\begin{array}{l}\text { Families with either L1 or L2 } \\
\text { plants }\end{array}$ & 99 & 75.0 \\
$\begin{array}{l}\text { Families with only L1 plants } \\
\text { Families with both L1 and L2 } \\
\text { plants }\end{array}$ & 63 & 47.7 \\
$\begin{array}{l}\text { Families with only L2 plants } \\
\text { Families with S1 plants }\end{array}$ & 6 & 22.7 \\
$\begin{array}{l}\text { Families with (either L1 or L2) } \\
\text { and S1 plants }\end{array}$ & 82 & 4.5 \\
$\begin{array}{l}\text { Families with only L1 and S1 } \\
\text { plants }\end{array}$ & 54 & 83.3 \\
$\begin{array}{l}\text { Families with (both L1 and L2) } \\
\text { and S1 plants }\end{array}$ & 25 & 62.1 \\
$\begin{array}{l}\text { Families with only L2 and S1 } \\
\text { plants }\end{array}$ & 3 & 40.9 \\
$\begin{array}{l}\text { Families with (L1 or L2) and no } \\
\text { S1 plants }\end{array}$ & 6 & 18.9 \\
$\begin{array}{l}\text { Families with no (L1 or L2) and } \\
\quad \text { S1 plants }\end{array}$ & 17 & 2.3 \\
$\begin{array}{l}\text { Families with no (L1 or L2) and } \\
\text { no S1 plants }\end{array}$ & 16 & 4.5 \\
\hline
\end{tabular}

Table 5. Distribution of leaf (L1, L2) and stem (S1) resistance to infection by Austropuccinia psidii in plants grown from New Zealand provenance Leptospermum scoparium (mānuka) seed

\begin{tabular}{lcc}
\hline Resistance phenotype & $\begin{array}{c}\text { Total number of } \\
\text { plants }\end{array}$ & $\begin{array}{c}\text { Percentage of total } \\
\text { plants (\%) }\end{array}$ \\
\hline Total & 1,758 & 100 \\
Plants with either L1 or L2 & 452 & 25.7 \\
$\quad$ phenotype & 397 & 22.6 \\
Plants with L1 phenotype & 55 & 3.1 \\
Plants with L2 phenotype & 476 & 27.1 \\
Plants with S1 phenotype & 266 & 15.1 \\
Plants with (L1 or L2) and S1 & & \\
phenotype & 222 & 12.6 \\
Plants with L1 and S1 phenotype & 44 & 2.5 \\
Plants with L2 and S1 phenotype & 186 & 10.6 \\
$\begin{array}{l}\text { Plants with (L1 or L2) and no S1 } \\
\text { phenotype }\end{array}$ & & 11.9 \\
Plants with no (L1 or L2) and S1 & 210 & 62.3 \\
phenotype & & \\
Plants with no (L1 or L2) and no & 1096 & \\
S1 phenotype & &
\end{tabular}


For the more susceptible species, tree death has been reported occurring within 4 years of $A$. psidii first being detected in Australia (Carnegie et al. 2016; Pegg et al. 2018). Tree death is not limited to small trees, with dieback of mature overstory rainforest trees occurring as a result of rust infection.

With the addition of this resistance criterion (BTD1), only 13.3\% of the Kunzea spp. plants were triple (leaf, stem, and branch) infection resistant. Similarly to the mânuka families, a range of triple resistance plants were produced per family (from 1 to 6 , average 2.2 ), with half the 22 families producing just one triple-resistant plant

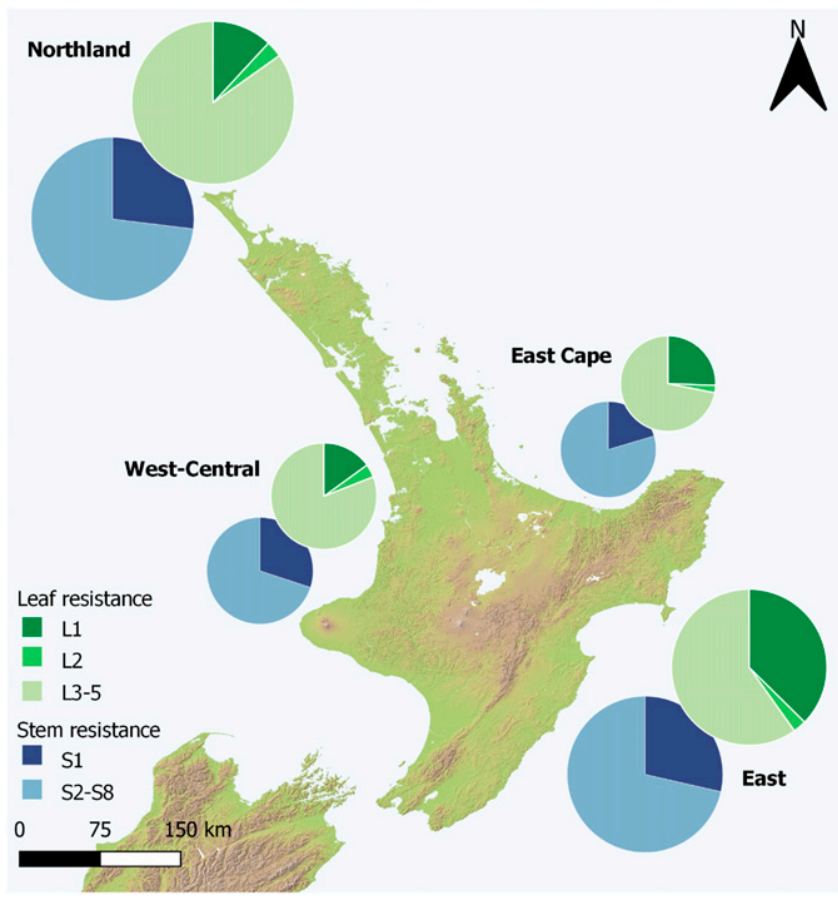

Fig. 4. Analysis of 1,758 Leptospermum scoparium (mānuka) plants from 132 seed families collected from four provenances of the North Island of New Zealand revealed that resistance to leaf and stem infection by Austropuccinia psidii varies between the provenances. Pie charts are sized to reflect the number of families from each provenance and the sectors within the pie charts illustrate the percentages of plants with leaf (green: L1 immune resistance, L2 hypersensitive resistance, and L3 to L5 susceptible) and stem (blue: S1 resistance and S2 to S8 susceptible) resistance phenotypes. Plants were grown from seed collected from mother plants within each provenance. per family. Similarly to mānuka, despite expressing one or two of the resistance phenotypes, many plants are likely to be field susceptible to infection by $A$. psidii, and the widespread presence of all three resistance mechanisms at the family level does not result in a high proportion of individual plants expressing these traits.

Only $1 \mathrm{M}$. excelsa plant from the 570 plants tested showed leaf (L1) resistance to infection by $A$. psidii, an alarming result given the cultural significance and ecological importance of this species. The number of plants tested per family ranged from 9 to 21 , with an average of 18.4 plants per seed family which were collected from the North Island provenances of Auckland, Bay of Plenty, Coromandel, and Northland, as per the Kunzea collections. Although the number of $M$. excelsa families and plants assessed is currently modest, it is larger than the amount of Kunzea germplasm that was assessed, where three different resistance mechanisms were found. The low level of resistance in M. excels $a$ is consistent with the findings of Sandhu and Park (2013), who scored this species, based on Australian-sourced plants and seed, as susceptible, the fifth grade on a six-criteria scale, where plants showed symptoms of "Fully developed pustules on leaves and medium to high in frequency". During the incursion response, Metrosideros spp., including pōhutukawa, were commonly found infected with $A$. psidii, although these data were collected at the genus level and not by species. These results indicate that natural infection of $M$. excelsa is occurring, and further monitoring of the susceptibility of this species as well as other Metrosideros spp. is recommended.

The seed collected in this study from mother plants growing in natural conditions are considered to have been cross-fertilized, because the Myrtaceae have late-acting self-incompatibility (Gibbs 2014). Although some myrtaceous species such as Eugenia uniflora and E. punicifolia are self-compatible (da Silva and Pinheiro 2009), results from crossing experiments with a small number of $M$. excelsa trees showed self-incompatibility (Schmidt-Adam et al. 1999). $L$. scoparium has been recorded as partly self-compatible (Anonymous 2019k). As noted above, L. scoparium is currently defined as an aggregate that requires critical reevaluation (de Lange 2014); thus, the partial self-compatibly noted by Anonymous (2019k) may be a consequence of complex interspecific interactions. For this study, seed from a family were considered to share a common genetic base derived from the mother tree and the remaining genetics were assumed to be contributed via cross-pollination. Thus, in-breeding depression or other mechanisms were considered unlikely to result in suppression of expression of potential resistance traits.

Tobias et al. (2016) noted that there are examples of naïve plant hosts expressing specific resistance to newly encountered pathogens, including the resistance to A. psidii in Australian native Myrtaceae species. In another rust system, white pine blister rust, resistance
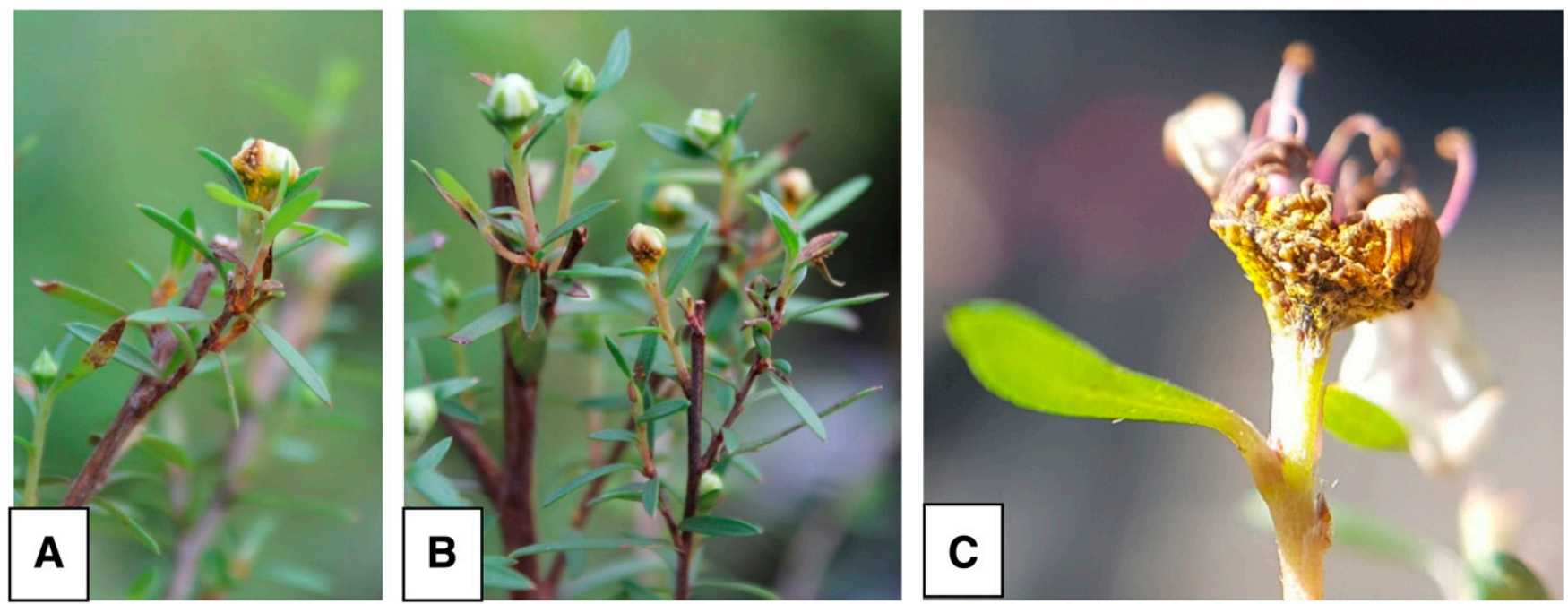

Fig. 5. Infection of A and B, flower buds and C, flowers of New Zealand provenance Leptospermum scoparium (mānuka) plants following inoculation of seedlings with Austropuccinia psidii resulting in uredia and urediniospore production on the flower (C). 
genes to the pathogen Cronartium ribicola were found in some species of Pinus when the Eurasian rust was introduced into North America, despite no previous exposure to this pathogen (Kinloch and Dupper 2002; Kinloch et al. 2003). These are examples of exceptions to the coevolution paradigm that assumes that resistance genes evolve from long-term coexistence of host and pathogen. A number of genetic loci have been identified in myrtaceous species; in particular, a range of Eucalyptus spp. that are associated with resistance to A. psidii. Junghans et al. (2003b) identified the first quantitative trait locus (QTL), Ppr1 (Puccinia psidii resistance 1), in Eucalyptus grandis, which was subsequently mapped to a region of chromosome 3 (Brondani et al. 2006; Mamani et al. 2010). Thumma et al. (2013) then found a collection of nucleotide-binding leucine-rich repeat (NB-LRR) genes in the same genomic region as Ppr1 in the E. grandis reference genome. Plant NB-LRR proteins are associated with resistance to a range of viral, bacterial, oomycete, and fungal pathogens and insect pests in plants (Dodds and Rathjen 2010). Butler et al. (2016) identified four QTLs in an outcross $\mathrm{F}_{2}$ family of E. globulus. Two QTLs, Ppr2 and Ppr3, were associated with the immune

Table 6. Distribution of leaf (L1, L2) and stem (S1) resistance to infection by Austropuccinia psidii in plants from seed families of New Zealand provenance Kunzea robusta (kānuka) and K. linearis (rawiri mānuka)

\begin{tabular}{lcc}
\hline Resistance phenotype & $\begin{array}{c}\text { Total number of } \\
\text { families }\end{array}$ & $\begin{array}{c}\text { Percentage of total } \\
\text { families (\%) }\end{array}$ \\
\hline $\begin{array}{l}\text { Total } \\
\text { Families with either L1 or L2 } \\
\text { plants }\end{array}$ & 28 & 100 \\
Families with only L1 plants & 27 & 96.4 \\
$\begin{array}{l}\text { Families with either L1 or L2 } \\
\text { plants }\end{array}$ & 13 & 7.1 \\
$\begin{array}{l}\text { Families with only L2 plants } \\
\text { Families with S1 plants }\end{array}$ & 12 & 46.4 \\
Families with either (L1 or L2) & 25 & 42.9 \\
$\quad$ and S1 plants & 25 & 89.3 \\
Families with only L1 and S1 \\
$\quad$ plants
\end{tabular}

${ }^{\mathrm{a}} \mathrm{BTD}=$ branch tip dieback.

Table 7. Distribution of leaf (L1, L2) and stem (S1) resistance to infection by Austropuccinia psidii in plants grown from New Zealand provenance Kunzea robusta (kānuka) and $K$. linearis (rawiri mānuka) seed

\begin{tabular}{lcc}
\hline Resistance phenotype $^{\mathbf{a}}$ & $\begin{array}{c}\text { Total number of } \\
\text { plants }\end{array}$ & $\begin{array}{c}\text { Percentage of total } \\
\text { plants (\%) }\end{array}$ \\
\hline Total & 362 & 100 \\
Plants with either L1 or L2 & 95 & 26.2 \\
$\quad$ phenotype & 30 & 8.3 \\
Plants with L1 phenotype & 65 & 18.0 \\
Plants with L2 phenotype & 68 & 18.8 \\
Plants with S1 phenotype & 56 & 15.5 \\
Plants with (either L1 or L2) and & & \\
$\quad$ S1 phenotype & 25 & 6.9 \\
Plants with L1 and S1 phenotype & 31 & 53.6 \\
Plants with L2 and S1 phenotype & 192 & \\
Plants with BTD1 (no branch tip & & \\
$\quad$ dieback) phenotype & 48 & \\
Plants with (either L1 or L2) and & & \\
S1 and BTD1 phenotype &
\end{tabular}

${ }^{\mathrm{a}} \mathrm{BTD}=$ branch tip dieback. response and two, Ppr4 and Ppr5, were associated with the hypersensitive response. The four QTLs were mapped to four linkage groups, none of which overlapped with the Ppr1 locus identified by Junghans et al. (2003b). Butler et al. (2016) concluded that resistance to A. psidii infection in Eucalyptus spp. is quantitative, resulting from the interaction of multiple loci. Recently, the genome of mānuka Crimson Glory has been assembled (Thrimawithana et al. 2019) and synteny between the mānuka chromosome 3 and the $E$. grandis chromosome 3 (location of Ppr1) was found.

Similarly to other naïve Myrtaceae species around the world, New Zealand provenance $L$. scoparium, $K$. robusta, and $K$. linearis have shown specific resistance to infection by $A$. psidii, expressing both a putative immune (L1) and hypersensitive (L2) leaf response. Additionally, all three species express a putative stem immune (S1) response and the two Kunzea spp. also express a specific BTD (BTD1) resistance. Although resistance to specific tissue infection is widespread in the families tested, in general, the number of plants that would be fully field resistant is limited, because only $15.1 \%$ of the mānuka families produced plants with a leaf (L1 or L2) and stem resistance phenotype. The number of Kunzea spp. families producing plants with both leaf and stem resistance was even higher (89\%), while $79 \%$ of the families produced plants with the triple (leaf, stem, and branch) resistance phenotypes. However, the number of tripleresistant Kunzea spp. plants was only $13.3 \%$ of the screened plants. It is likely that these four putatively independent resistances are mediated via a collective of QTLs based on results from studies of other Myrtaceae species (Brondani et al. 2006; Butler et al. 2016; Junghans et al. 2003b; Mamani et al. 2010; Thumma et al. 2013). How these resistance mechanisms relate and interact with other plant traits, including bioactive compounds found in nectar, timing of flowering, or leaf oil composition, is currently unknown.

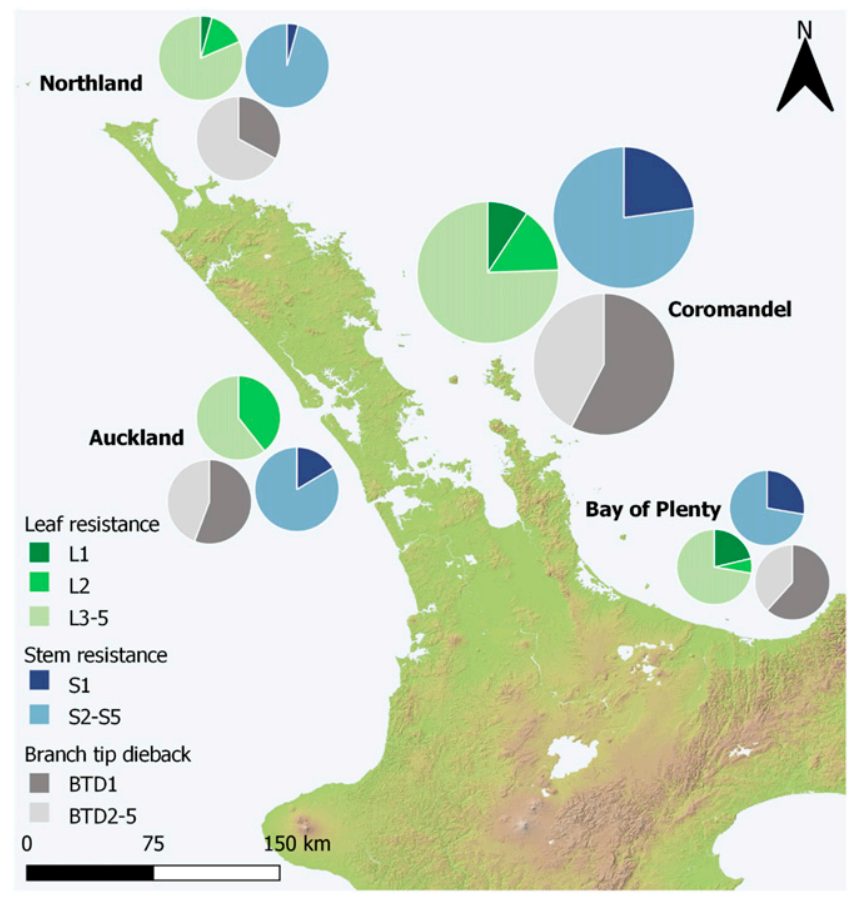

Fig. 6. Analysis of 292 Kunzea robusta (Auckland, Coromandel, and Bay of Plenty) and $70 \mathrm{~K}$. linearis (Northland) (kānuka) plants from 28 seed families collected from four provenances of the North Island of New Zealand revealed that resistance to leaf and stem infection and branch tip dieback (BTD) by Austropuccinia psidii varies between the provenances. Pie charts are sized to reflect the number of families from each provenance and the sectors within the pie charts illustrate the percentages of plants with leaf (green: L1 immune resistance, L2 hypersensitive resistance, and L3 to L5 susceptible), stem (blue: S1 resistance and S2 to S8 susceptible), and BTD (gray: BTD1 resistant and BTD2 to BTD5 susceptible) resistance phenotypes. Plants were grown from seed collected from mother plants within each provenance. 
Table 8. Summary of leaf resistance phenotypes of plants grown from New Zealand provenance Metrosideros excelsa (pōhutukawa), Lophomyrtus bullata (ramarama), and L. obcordata (rōhutu) seed

\begin{tabular}{lccccccr}
\hline & & & \multicolumn{4}{c}{$\begin{array}{c}\text { Number of plants by } \\
\text { resistance phenotype }\end{array}$} \\
\cline { 5 - 8 } Species & $\begin{array}{c}\text { Number of } \\
\text { families }\end{array}$ & $\begin{array}{c}\text { Number of } \\
\text { plants }\end{array}$ & L1 & L2 & L3 & L4 & L5 \\
\hline M. excelsa & 31 & 570 & 1 & 0 & 75 & 172 & 322 \\
L. bullata & 3 & 56 & 0 & 0 & 1 & 3 & 52 \\
L. obcordata & 1 & 5 & 0 & 0 & 1 & 1 & 3 \\
\hline
\end{tabular}

Selecting for tolerance to A. psidii rather than complete resistance may be more beneficial from a commercial perspective but also allow for selection of greater genetic diversity for reestablishment of natural populations if required. Lemon myrtle (Backhousia citriodora) is a commercially important Australian Myrtaceae species grown for oil and leaf products. Examination of the populations across provenances has failed to identify resistance (Lee et al. 2016). However, some degrees of tolerance to A. psidii have been identified and are currently being assessed for their suitability under commercial production conditions (E. Lancaster, unpublished). The demonstration that basidiospores are infective and the resulting sori recombinant (McTaggart et al. 2018) will also need to be considered in management options such as breeding or selection of resistant or tolerant plant lineages.

Although the effects of A. psidii on New Zealand Myrtaceae species have been largely focused on the susceptibility of $L$. bullata and $L$. orbcordata, and acknowledging that spore concentration and the temperature and humidity in the inoculation chambers used in this study were ideal for spore germination and infection and that these conditions are unlikely to occur with great frequency in many natural environments in New Zealand, the findings from this study suggest that there is a significant long-term risk to the wider range of ecologically, culturally, and commercially significant Myrtaceae species. The arrival of $A$. psidii also highlights that New Zealand, similar to many other countries, has limited strategies in place to address the long-term consequences of exotic pests and pathogens on natural flora. New Zealand has no significant national collections of endemic or native germplasm similar to those at PlantBank at the Australian Botanic Garden at Mount Annan, New South Wales (Anonymous 20191). This is the first detailed report of A. psidii infection on New Zealand provenance $L$. scoparium: only a limited number of plants flowered during this investigation and a broader study is required to examine the field impacts of $A$. psidii infection on flower production, survival, and pollination processes, including on those lineages considered resistant based on foliage and stem symptoms. Although New Zealand's native Myrtaceae species are taonga, there is limited understanding of their full ecological roles in different ecosystems. Strategies to maintain or increase natural ecosystem resilience to the impacts of his pathogen will need to be based on an understanding of the ecological roles, including mâtauranga (knowledge) Māori, as well as the consequences of the long-term interactions of this sexually reproducing, biotrophic pathogen with a wide host range.

\section{Acknowledgments}

We thank mana whenua and landowners for kindly allowing scientists and seed collectors access to their lands to receive plant samples and undertake this research.

\section{Literature Cited}

Allen, R. B., Partridge, T. R., Lee, W. G., and Efford, M. 1992. Ecology of Kunzea ericoides (A. Rich.) J. Thompson (kanuka) in east Otago, New Zealand, New Zealand. J. Bot. 30:135-149.

Anonymous. 2015. Hawaii Invasive Species Council Final Report. https:// dlnr.hawaii.gov/hisc/files/2013/05/FY14-DOFAW-HISC-Rust-Surveillance-FINALREPORT.pdf

Anonymous. 2019a. Serious fungal plant disease found on Raoul Island trees. https://www.mpi.govt.nz/news-and-resources/media-releases/serious-fungal-plantdisease-found-on-raoul-island-trees/
Anonymous. 2019b. Response underway following myrtle rust find. https:// www.beehive.govt.nz/release/response-underway-following-myrtle-rust-find

Anonymous. 2019c. Myrtle rust appears in Taranaki. https://www.mpi.govt.nz/ news-and-resources/media-releases/myrtle-rust-appears-in-taranaki/

Anonymous. 2019d. Te Araroa and East Cape. https://www.newzealand.com/int/ feature/te-araroa-and-east-cape/

Anonymous. 2019e. Leptospermum — family Myrtaceae. Commonly known as 'teatrees'. https://www.anbg.gov.au/leptospermum/

Anonymous. 2019f. Mānuka/kahikātoa and kānuka. https://www.doc.govt.nz/ nature/native-plants/manuka-kahikatoa-and-kanuka/

Anonymous. 2019g. Apiculture: Ministry for Primary Industries 2016 Apiculture Monitoring Programme. https://www.mpi.govt.nz/dmsdocument/16621

Anonymous. 2019h. Treaty of Waitangi. http://www.treatyofwaitangi.maori.nz/

Anonymous. 2019i. About the Waitangi Tribunal. https://waitangitribunal.govt.nz/ about-waitangi-tribunal/

Anonymous. 2019j. Myrtle Rust Update September 2018. https://www.biosecurity. govt.nz/dmsdocument/31599-myrtle-rust-newsletter-september-2018

Anonymous. 2019k. Leptospermum scoparium (manuka). Invasive Species Compendium. https://www.cabi.org/isc/datasheet/30097

Anonymous. 20191. Australian PlantBank. The Royal Botanic Garden Sydney. https://www.rbgsyd.nsw.gov.au/Science/Australian-plantbank

Beenken, L. 2017. Austropuccinia: A new genus name for the myrtle rust pathogen Puccinia psidii placed within the redefined family Sphaerophragmiaceae (Pucciniales). Phytotaxa 297:53-61.

Berthon, K., Esperon-Rodriguez, M., Beaumont, L. J., Carnegie, A. J., and Leishman, M. R. 2018. Assessment and prioritisation of plant species at risk from myrtle rust (Austropuccinia psidii) under current and future climates in Australia. Biol. Conserv. 218:154-162.

Brondani, R. P., Williams, E. R., Brondani, C., and Grattapaglia, D. 2006. A microsatellite-based consensus linkage map for species of Eucalyptus and a novel set of 230 microsatellite markers for the genus. BMC Plant Biol. 6:20.

Butler, J. B., Freeman, J. S., Vaillancourt, R. E., Potts, B. M., Glen, M., Lee, D. J., and Pegg, G. S. 2016. Evidence for different QTL underlying the immune and hypersensitive responses of Eucalyptus globulus to the rust pathogen Puccinia psidii. Tree Genet. Genomes 12:39.

Buys, M. H., Flint, H. J., Miller, E. M., Yao, H., Caird, A. R., and Ganley, R. J. 2016. Preparing for the invasion: Efficacy of DNA barcoding to discern the host range of myrtle rust (Puccinia psidii) among species of Myrtaceae. Forestry 89:263-270.

Buys, M. H., Winkworth, R. C., de Lange, P. J., Wilson, P. G., Mitchell, N., Lemmon, A. R., Lemmon, E. M., Holland, S., Cherry, J. R., and Klápště, J. 2019. The phylogenomics of diversification on an island: Applying anchored hybrid enrichment to New Zealand Leptospermum scoparium (Myrtaceae) Bot. J. Linn. Soc. 191:1-17.

Bylsma, R. J., Clarkson, B. D., and Efford, J. T. 2014. Biological flora of New Zealand 14: Metrosideros excelsa, pōhutukawa, New Zealand Christmas tree. N. Z. J. Bot. 52:365-385

Carnegie, A. J. 2015. First report of Puccinia psidii (myrtle rust) in Eucalyptus plantations in Australia. Plant Dis. 99:161.

Carnegie, A. J., Kathuria, A., Pegg, G. S., Entwistle, P., Nagel, M., and Giblin, F. R. 2016. Impact of the invasive rust Puccinia psidii (myrtle rust) on native Myrtaceae in natural ecosystems in Australia. Biol. Invasions 18:127-144.

Carnegie, A. J., Lidbetter, J. R., Walker, J., Horwood, M. A., Tesoriero, L., Glen, M., and Priest, M. J. 2010. Uredo rangelii, a taxon in the guava rust complex, newly recorded on Myrtaceae in Australia. Australas. Plant Pathol. 39:463-466.

Christenhusz, M., and Byng, J. W. 2016. The number of known plant species in the world and its annual increase. Phytotaxa 261:201-217.

da Silva, A. L. G., and Pinheiro, M. C. B. 2009. Reproductive success of four species of Eugenia L. (Myrtaceae). Acta Bot. Bras. 23:526-534.

de Lange, P. J. 2014. A revision of the New Zealand Kunzea ericoides (Myrtaceae) complex. PhytoKeys 40:1-185.

de Lange, P. J., and Rolfe, J. R. 2010. New Zealand Indigenous Vascular Plant Checklist. New Zealand Plant Conservation Network, Wellington, New Zealand. http://nzpcn.org.nz/publications/de_Lange_PJ_and_Rolfe_J_2010.pdf

Dodds, P. N., and Rathjen, J. P. 2010. Plant immunity: Towards an integrated view of plant-pathogen interactions. Nat. Rev. Genet. 11:539-548.

du Plessis, E., Granados, G. M., Barnes, I., Ho, W. H., Alexander, B. J. R., Roux, J., and McTaggart, A. R. 2019. The pandemic strain of Austropuccinia psidi causes myrtle rust in New Zealand and Singapore. Australas. Plant Pathol. 48:253-256.

Dymond, J. R., Shepherd, J. D., Newsome, P. F., and Belliss, S. 2017. Estimating change in areas of indigenous vegetation cover in New Zealand from the New Zealand Land Cover Database (LCDB). N. Z. J. Ecol. 41:56-64.

Freeman, J. S., Hamilton, M. G., Lee, D. J., Pegg, G. S., Brawner, J. T., Tilyard, P. A., and Potts, B. M. 2019. Comparison of host susceptibility to native and exotic pathogens provides evidence for pathogen imposed selection in forest trees. New Phytol. 221:2261-2272.

Gibbs, P. E. 2014. Late-acting self-incompatibility-The pariah breeding system in flowering plants. New Phytol. 203:717-734.

Giblin, F. 2013. Myrtle rust report: New Caledonia. University of the Sunshine Coast, Maroochydore, QLD, Australia. https://davar.gouv.nc/sites/default/files/ atoms/files/rapport_de_mission_de_fiona_giblin_universite_de_la_sunshine_coast_australie.pdf 
Ho, W. H., Baskarathevan, J., Griffin, R. L., Quinn, B. D., Alexander, B. J. R., Havell, D., Ward, N. A., and Pathan, A. K. 2019. First report of myrtle rust caused by Austropuccinia psidii on Metrosideros kermadecensis on Raoul Island and on M. excelsa in Kerikeri, New Zealand. Plant Dis. 103:2128.

Hood, I. 2016. Myrtle Rust and the New Zealand Forest Industry. Report for New Zealand Forest Owners Association. https://nzppi.co.nz/documents/pests/mytlerust-scion-foa-forestry.pdf

Junghans, D. T., Alfenas, A. C., Brommonschenkel, S. H., Oda, S., Mello, E. J., and Grattapaglia, D. 2003b. Resistance to rust (Puccinia psidii Winter) in Eucalyptus: Mode of inheritance and mapping of a major gene with RAPD markers. Theor. Appl. Genet. 108:175-180.

Junghans, D. T., Alfenas, A. C., and Maffia, L. A. 2003a. Escala de notas para quantificação da ferrugem em Eucalyptus. Fitopatol. Bras. 28:184-188.

Kawanishi, T., Uemastu, S., Kakishima, M., Kagiwada, S., Hamamoto, H., Horie, H., and Namba, S. 2009. First report of rust disease on ohia and the causal fungus, Puccinia psidii, in Japan. J. Gen. Plant Pathol. 75:428-431.

Kinloch, B. B., Jr., and Dupper, G. E. 2002. Genetic specificity in the white pineblister rust pathosystem. Phytopathology 92:278-280.

Kinloch, B. B., Jr., Sniezko, R. A., and Dupper, G. E. 2003. Origin and distribution of $\mathrm{Cr} 2$, a gene for resistance in white pine blister rust in natural populations of western white pine. Phytopathology 93:691-694.

Lee, D., Brawner, J., and Pegg, G. 2015. Screening Eucalyptus cloeziana and E. argophloia populations for resistance to Austropuccinia psidii. Plant Dis. 99: 71-79.

Lee, D., Doran, J., Pegg, G., Lea, D., Macdonell, P., and Giblin, F. 2016. Myrtle Rust Screening in Lemon Myrtle Provenance Plantings. RIRDC Publ. No. 16/ 012 RIRDC Project No. PRJ-008883.

Lu, J., Carter, D. A., Turnbull, L., Rosendale, D., Hedderley, D., Stephens, J., Gannabathula, S., Steinhorn, G., Schlothauer, R. C., Whitchurch, C. B., and Harry, E. J. 2013. The effect of New Zealand kanuka, manuka and clover honeys on bacterial growth dynamics and cellular morphology varies according to the species. PLoS One 8:e55898.

Mamani, E. M., Bueno, N. W., Faria, D. A., Guimarães, L. M., Lau, D., Alfenas, A. C., and Grattapaglia, D. 2010. Positioning of the major locus for Puccinia psidii rust resistance (Ppr1) on the Eucalyptus reference map and its validation across unrelated pedigrees. Tree Genet. Genomes 6:953-962.

McTaggart, A. R., Roux, J., Granados, G. M., Gafur, A., Tarrigan, M., Santhakumar, P., and Wingfield, M. J. 2016. Rust (Puccinia psidii) recorded in Indonesia poses a threat to forests and forestry in South-East Asia. Australas. Plant Pathol. 45:83-89.

McTaggart, A. R., Shuey, L. S., Granados, G. M., du Plessis, E., Fraser, S., Barnes, I., Naidoo, S., Wingfield, M. J., and Roux, J. 2018. Evidence that Austropuccinia psidii may complete its sexual life cycle on Myrtaceae. Plant Pathol. 67:729-734.

Morin, L., Aveyard, R., Lidbetter, J. R., and Wilson, P. G. 2012. Investigating the host-range of the rust fungus Puccinia psidii sensu lato across tribes of the family Myrtaceae present in Australia. PLoS One 7:e35434.

Mulcock, A. P. 1954. A disease of manuka Leptospermum scoparium Forst. Trans. R. Soc. N.Z. 82:115-118.

Pegg, G. S., Brawner, J. T., and Lee, D. J. 2014. Screening Corymbia populations for resistance to Puccinia psidii. Plant Pathol. 63:425-436.
Pegg, G. S., Lee, D. J., and Carnegie, A. J. 2018. Predicting impact of Austropuccinia psidii on populations of broad leaved Melaleuca species in Australia. Australas. Plant Pathol. 47:421-430.

Pegg, G. S., Taylor, T., Entwistle, P., Guymer, G., Giblin, F. G., and Carnegie, A. J 2017. Impact of Austropuccinia psidii (myrtle rust) on Myrtaceae-rich wet sclerophyll forests in south east Queensland. PLoS One 12:e0188058.

Roux, J., Germishuizen, I., Nadel, R., Lee, D. J., Wingfield, M. J., and Pegg, G. S. 2015. Risk assessment for Puccinia psidii becoming established in South Africa. Plant Pathol. 64:1326-1335.

Sandhu, K. S., and Park, R. F. 2013. National Myrtle Rust Transition to Management (T2M) Program. Final Report. Genetic basis of pathogenicity in Uredo rangelii. https://www.planthealthaustralia.com.au/wp-content/uploads/ 2018/10/National-Myrtle-Rust-Transition-to-Management-Program-Final-ReportGenetic-basis-of-pathogenicity-in-Uredo-rangelii.pdf

Schmidt-Adam, G., Gould, K. S., and Murray, B. G. 1999. Floral biology and breeding system of pohutukawa (Metrosideros excelsa, Myrtaceae). N. Z. J. Bot. 37:687-702

Smallfield, B. M., Joyce, N. I., and van Klink, J. W. 2018. Developmental and compositional changes in Leptospermum scoparium nectar and their relevance to mānuka honey bioactives and markers. N. Z. J. Bot. 56:183-197.

Soewarto, J., Giblin, F., and Carnegie, A. J. 2019. Austropuccinia psidii (myrtle rust) global host list, version 2. Australian Network for Plant Conservation, Canberra, ACT, Australia. https://www.anpc.asn.au/myrtle-rust

Stewart, J. E., Ross-Davis, A. L., Graça, R. N., Alfenas, A. C., Peever, T. L., Hanna, J. W., Uchida, J. Y., Hauff, R. D., Kadooka, C. Y., Kim, M.-S. Cannon, P. G., Namba, S., Simeto, S., Pérez, C. A., Rayamajhi, M. B., Lodge, D. J., Arguedas, M., Medel-Ortiz, R., López-Ramirez, M. A., Tennant, P., Glen, P., Machado, P. S., McTaggart, A. R., Carnegie, A. J., and Klopfenstein, N. B. 2018. Genetic diversity of the myrtle rust pathogen (Austropuccinia psidii) in the Americas and Hawaii: Global implications for invasive threat assessments. For. Pathol. 48:e12378.

Thrimawithana, A. H., Jones, D., Hilario, E., Grierson, E., Ngo, H. M., Liachko, I., Sullivan, S., Bilton, T. P., Jacobs, J. M. E., Bicknell, R., David, C., Deng, C., Nieuwenhuizen, N., Lopez-Girona, E., Tobias, P. A., Morgan, E., Perry, N. B., Lewis, D. H., Crowhurst, R., Davies, K. M., Chagné, D., and Schwinn, K. E. 2019. A whole genome assembly of Leptospermum scoparium (Myrtaceae) for mānuka research. N. Z. J. Crop Hortic. Sci. 47: 233-260.

Thumma, B., Pegg, G. S., Warburton, P., Brawner, J., Macdonell, P., Yang, X., and Southerton, S. 2013. Molecular tagging of rust resistance genes in eucalypts. https://www.planthealthaustralia.com.au/wp-content/uploads/2018/10/Moleculartagging-of-rust-resistance-in-eucalypts.pdf

Tobias, P. A., Guest, D. I., Külheim, C., Hsieh, J. F., and Park, R. F. 2016. A curious case of resistance to a new encounter pathogen: Myrtle rust in Australia. Mol. Plant Pathol. 17:783-788.

Uchida, J., Zhong, S., and Kilgore, E. 2006. First report of a rust disease on 'ōhi'a caused by Puccinia psidii in Hawaii. Plant Dis. 90:524

Wiser, S. K., and Hurst, J. M. 2008. Classification of New Zealand forest and shrubland communities based on national plot sampling on an 8-km grid. https://www.landcareresearch.co.nz/publications/researchpubs/Wiser_Hurst_ Vegetation_Classification_2008.pdf

Zhuang, J.-Y., and Wei, S.-X. 2011. Additional materials for the rust flora of Hainan Province, China. Mycosystema 30:853-860. 